\title{
Preliminary Results on Behavior of Transgenic and Conventional Plum to Natural PPV Infection in a New Field Trial
}

\author{
Ioan ZAGRAI*, Luminița ZAGRAI, Angela FEŞTILĂ \\ Fruit Research \& Development Station Bistrița, Romania \\ *)Corresponding author, e-mail: izagrai@yahoo.com \\ BulletinUASVM Horticulture 73(2) / 2016 \\ Print ISSN 1843-5254, Electronic ISSN 1843-5394 \\ DOI:10.15835/buasvmcn-hort:12292
}

\begin{abstract}
To assess the durability of resistance to PPV of 'HoneySweet' transgenic plum harbouring plum pox virus (PPV) capsid gene, a new field trial was recently established in Romania at Fruit Research \& Development Station Bistrita. 'Stanley' and 'Reine Claude d'Althan' cvs. were used as control. PPV inoculum source was secured within the experimental plot. PPV monitoring was made by visual observations of symptoms development on leaves and by serological (DAS-ELISA) and molecular (IC/-RT-PCR) testings. Three years after tree planting PPV was observed and detected only on 'Stanley'. 'HoneySweet' and 'Reine Claude d'Althan' cultivars remained PPV free.
\end{abstract}

Keywords: natural infection, PPV., transgenic plum

\section{Introduction}

Plum pox virus (PPV) is the causal agent of sharka, one of the most devastating diseases of Prunus species (Cambra et al., 2006). In order to restrict the spread of PPV, European and Mediterranean Plant Protection Organization recommended measures such as quarantine isolation, nursery and orchard survey, propagation of virus-free Prunus and chemical treatment of trees against aphid vectors. These measures have appeared to be ineffective in halting the spread of PPV which is endemic in many countries. Due to the rapid spread of PPV by aphids and the presence of many potential hosts, sharka disease is difficult to eradicate once it has become established in an area. Therefore, the use of resistant cultivars represents an important strategy to control PPV.

In the context of the paucity of natural resistance, few transgenic clones of Prunus domestica L. carrying the CP gene of Plum pox virus (PPV) were developed to obtain PPV resistant plums (Scorza et al., 1994). One transgenic line, C5, subsequently named 'HoneySweet' (Scorza et al., 2007) was found to be highly resistant to graft- and aphid-mediated inoculation by PPV in greenhouse and field tests (Ravelonandro et al., 1997, 2001; Malinowski et al., 2006, Polak et. al., 2008, Zagrai et al., $2008 \mathrm{a}, \mathrm{b}$ ).

\section{Aims and objectives}

The goal of the study was to continue monitoring the durability and stability of resistance to Plum pox virus in 'HoneySweet' transgenic plum in a new field trial.

\section{Materials and methods}

The study on resistance to PPV of 'HoneySweet' transgenic plum is continued in Romania at Fruit Research \& Development Station Bistrita, with a new field trial established in 2013 under the required permitting. The plot is surrounded by a large apple orchard so that a buffer zone of minimum $500 \mathrm{~m}$ it was necessary to be secured. The experimental plot was arranged in 12 blocks of 4 trees (two trees of ,Honey Sweet', one tree of Stanley and one tree of Reine Claude d'Althan) each. Prunus cerasifera and Prunus spinosa were interspersed for coexistance studies (data not 
show). Source of PPV inoculum was provided by infected plums grown in pots. Limited treatments with insecticides were made within the experimental plot in order to stimulate the virus spread by aphids. PPV monitoring was made by visual observation (three times per year) and by DAS-ELISA (Double Antibody Sandwich - Enzyme Linked Immunosorbent Assay) and IC/-RTPCR (Immunocapture/-Reverse TranscriptionPolymerase Chain Reaction) testings.

\section{Results and discussion}

No PPV symptoms were observed both on 24 transgenic and $12+12$ conventional plums from the experimental plot on 2014 and 2015. DAS-ELISA has confirmed the PPV free status in all those trees. PPV infected trees were found in Prunus cerasifera and Prunus spinosa since 2014, probable due to previous infection. Also, in the spring of 2016 no PPV symptoms were observed on 'HoneySweet' and 'Reine Claude d'Althan' cvs. Typical PPV symptoms were observed on one tree belonging to Stanley, and DAS-ELISA and IC-RTPCR confirmed the virus infection.

\section{Conclusion}

PPV infection was recorded within experimental plot on Stanley cv, three years after planting, 'HoneySweet' and 'Reine Claude d'Althan' cultivars remained PPV free.

Acknowledgement. The financial support for this work was provided by the Romanian Ministry of Agriculture and Rural Development, contract ADER 4.1.3. / 2015.

\section{REFERENCES}

1. Cambra M, Capote N, Myrta A, Llacer G (2006). Plum pox virus and the estimated costs associated with sharka disease. OEPP/EPPO Bull. 36:202-204.

2. Malinowski T, Cambra M, Capote N, Zawadska B, Gorris MT, Scorza R, Ravelonadro M (2006). Field trials of plum clones transformed with the Plum pox virus coat protein (PPV-CP)gene. Plant Dis 90:1012-1018.

3. Polak J, Pivalova J, Kumar J, Jokes M, Scorza R, Ravelonandro M (2008). Behaviour of transgenic Plum pox virus-resistant Prunus domestica L. clone C5 grown in the open field under a high and permanent infection pressure of the PPV-REC strain. J Plant Pathol 90:33-36.

4. Ravelonandro M, Scorza R, Bachelier JC, Labonne G, Levy L, Damsteegt V, Callahan A.M. and Dunez J (1997) Resistance of transgenic Prunus domestica to plum pox virus infection. Plant Disease, 81: 1231-1235.

5. Ravelonandro M, Briard P, Scorza R (2001). Significant resistance of transgenic plums against the four serotypes of plum pox potyvirus. Acta Acta Horticulturae 550:431435.

6. Scorza R, Ravelonandro M, Callahan AM, Cordts JM, Fuchs M, Dunez J, Gonsalves D (1994). Transgenic plums (Prunus domestica) express the Plum pox virus coat protein gene. Plant Cell Rep 14:18-22.

7. Scorza R, Hily J.M., Callahan A, Malinovki T., Cambra M, Capote N, Zagrai I, Damsteegt V, Briard P, Ravelonandro M (2007). Deregulation of Plum Pox Resistant Transgenic Plum "HoneySweet". Acta Horticulturae, 738: 669-674.

8. Zagrai I, Ravelonandro M, Scorza R, Minoiu N, Zagrai L (2008a). Field release of transgenic plums in Romania. Bulletin of University of Agricultural Sciences and Veterinary Medicine Cluj-Napoca. Anim. Sci. Biotechnol. 65:358-365 ISSN 1843-5262.

9. Zagrai I, Capote N, Ravelonandro M, Cambra M, Zagrai L, Scorza R (2008b). Plum pox virus silencing of C5 transgenic plums is stable under challenge inoculation with heterologous viruses. J Plant Pathol 90:63-71. 